Osborne Clarke is one of Europe's most respected law firms and a UK leader in advising marketers on the legal issues affecting them. The firm's website, MarketingLaw.co.uk, has provided marketers with authoritative legal insights for over 10 years. Please send any queries regarding this column to Stephen Groom (Stephen. groom@osborneclarke .com)

\section{What happened}

\section{Legal and Regulatory Update}

\section{Consumer protection from unfair trading (amendment) regulations 2013}

\author{
Maxine Finding \\ Journal of Direct, Data and Digital Marketing Practice (2013) 15, 140-141. \\ doi:10.1057/dddmp.2013.57
}

Who: Department for Business Innovation and Skills (BIS)

Where: The United Kingdom

When: 6 August 2013

Law stated as at: 1 October 2013

On 6 August 2013, BIS published the Draft Consumer Protection from Unfair Trading (Amendment) Regulations 2013 (the 'Draft Regulations'). The Draft Regulations will amend the Consumer Protection from Unfair Trading Regulations 2008 (the '2008 Regulations') in two main ways: first, they will introduce a direct right to redress for a consumer in respect of misleading and aggressive practices; and secondly, they will extend the scope of the 2008 Regulations to cover misleading and aggressive demands for payment. The new consumer right to redress is set out in more detail below.

The Draft Regulations propose inserting a new section 4A into the 2008 Regulations, which will incorporate a direct right to redress for consumers. Broadly, a consumer will have the right to redress if:

1. the consumer contracts with a trader for the sale or supply of a product, or the consumer makes a payment to a trader in relation to the product;

2. the trader engages in a 'prohibited practice' in relation to the product, that is, a misleading action or an aggressive practice (it is important to note that while the rest of the 2008 Regulations also apply to misleading omissions, the new section 4A does not); and

3. the prohibited practice is a significant factor in the consumer's decision to enter into the contract or make the payment.

Three new rights of redress are proposed by the Draft Regulations: the right to unwind, the right to a discount and the right to damages.

The right to unwind can apply in three situations:

(a) a contract for the sale or supply of a product by a trader to a consumer;

(b) the sale or supply of a product by a consumer to a trader (eg a used car sold by a consumer to a used car dealer; and 
25 to 100 per cent or 'appropriate' discounts

New right to damages

Why this matters (c) a payment made by a consumer to a trader where that payment was not required to be made.

In relation to the sale or supply of a product by a trader to a consumer, the right can only be exercised within 90 days of the sale or supply. It must also be possible to reject the product, which essentially means that it cannot have been fully consumed, performed, expired or exercised.

The new right to a discount is calculated based on the severity of the prohibited practice (to be assessed by reference to the behaviour of the person who engaged in the practice, the impact of the practice on the consumer and the time that has elapsed since the prohibited practice took place). We note that while the right is called the right to a discount, it also encompasses a right to a refund if the consumer has already made payments.

The percentage discount varies from 25 per cent for a minor prohibited practice to 100 per cent for a very serious prohibited practice. If the product is worth over $£ 5,000$, or if the value of the product is lower than the amount payable under the contract, the percentages set out in the Draft Regulations will not apply, and the discount will be of the 'appropriate' amount, calculated on a case-by-case basis.

The Draft Regulations also propose a right to damages if the consumer has suffered financial loss as a result of the prohibited practice that he would not otherwise have suffered. A consumer may also have a right to damages if he has suffered alarm, distress, physical discomfort or inconvenience that he would not have otherwise suffered. However, this only applies where a significant purpose of the contract was to provide pleasure, relaxation or peace of mind, and damages in such a case would be limited to those that are 'restrained and modest'.

Consumer Focus has reported that over 60 per cent of the population had been the target of an unfair commercial practice and that the total detriment suffered by consumers in 2009 as a result of misleading and aggressive practices was around $£ 3.3 \mathrm{bn}$. The new right will make it simpler for consumers to take action against traders, and legitimate businesses can be more confident that traders who use misleading and aggressive practices will have action taken against them.

Advertisers and their advertising service suppliers should be watching closely. If these new rights become law, changes may be needed to contractual provisions and to insurance arrangements and, if and when US-style class actions become a reality, they could be potential game changers for the advertising industry as a whole.

BIS asked for comments on the proposals by 11 October 2013. There is still no sign of such direct rights of redress being given to competitors of traders and advertisers who breach the 2008 Regulations.

Maxine Finding, Associate, Osborne Clarke Bristol 